\title{
Scapular Free Vascularised Bone Flaps for Mandibular Reconstruction: Are Dental Implants Possible?
}

\author{
Martin Lanzer ${ }^{1}$, Thomas Gander ${ }^{1}$, Klaus Grätz ${ }^{1}$, Claudio Rostetter ${ }^{1}$, Daniel Zweifel ${ }^{1}$, Marius \\ Bredell $^{1}$
}

${ }^{1}$ Clinic for Cranio-Maxillofacial Surgery, University Hospital of Zurich, Zurich, Switzerland.

\author{
Corresponding Author: \\ Martin Lanzer \\ Frauenklinikstrasse 24, 8091, Zurich \\ Switzerland \\ Phone: 0041(044)2555064 \\ Fax: 0041(044)25554179 \\ E-mail: martin.lanzer@usz.ch
}

\begin{abstract}
Objectives: Free fibula flap remains the flap of choice for reconstruction of mandibular defects. If free fibula flap is not possible, the subscapular system of flaps is a valid option. In this study, we evaluated the possibility of dental implant placement in patients receiving a scapular free flap for oromandibular reconstruction.

Material and Methods: We retrospectively reviewed 10 patients undergoing mandible reconstruction with a subscapular system free-tissue (lateral border of the scapula) transfer at the University Hospital Zürich between January 1, 2010 and January 1, 2013. Bone density in cortical and cancellous bone was measured in Hounsfield units (HU). Changes of bone density, height and width were analysed using IBM SPSS Statistics 22. Comparisons of bone dimensions as well as bone density were performed using a chi-square test.

Results: Ten patients were included. Implantation was conducted in 50\%. However, all patients could have received dental implants considering bone stock. Loss of bone height and width were significant $(\mathrm{P}<0.001)$. There was a statistical significant increase in bone density in cortical $(\mathrm{P}<0.001)$ and cancellous $(\mathrm{P}=0.004)$ bone.

Conclusions: Dental implants are possible after scapular free flap reconstruction of oromandibular defects. Bone height and width were reduced, while bone density increased with time.
\end{abstract}

Keywords: bone; bone transplantation; dental implants; free tissue transfer flap; mandibular reconstruction.

\author{
Accepted for publication: 4 September 2015 \\ To cite this article: \\ Lanzer M, Gander T, Grätz K, Rostetter C, Zweifel D, Bredell M. \\ Scapular Free Vascularised Bone Flaps for Mandibular Reconstruction: Are Dental Implants Possible? \\ J Oral Maxillofac Res 2015;6(3):e4. \\ URL: http://www.ejomr.org/JOMR/archives/2015/3/e4/v6n3e4.pdf \\ doi: $10.5037 /$ jomr.2015.6304
}




\section{INTRODUCTION}

Reconstruction of mandibular defects using microvascular flap techniques is a common procedure with very good functional and aesthetic outcome. The procedure is associated with an acceptable incidence of donor- and recipient-site complications resulting in minimal long-term morbidity [1]. There are currently four types of osseous free flaps: fibular free flaps (FFFs); subscapular system free flaps, including the lateral scapular border flaps (LSBFs) and the scapular tip free flaps (STFFs); iliac crest free flaps (ICFFs); and radial forearm osseous free flaps (ROFFs) [2] .

FFF is the flap of choice for reconstruction of mandibular defects. The reasons include its anatomic reliability, ease of elevation, ability to use a two-team approach, and its acceptable donor-site morbidity [3]. With a FFF, most soft tissue defects can be reconstructed with a reliable fasciocutaneous paddle. It has been demonstrated that the FFF can be osteotomised multiple times, preferably with segments of $2 \mathrm{~cm}$ or more to improve the shape of the mandible. The bone stock is more than sufficient for implants, and hence offers a great opportunity for prosthetic rehabilitation while reducing morbidity. There are only a few situations in which FFF is not recommended: 1) in case of extensive through-andthrough tissue defects and when a large amount of supporting tissue is required, the fasciocutaneous paddle might not be large enough to cover the entire defect; 2) in case of a lack of 3-arterial vessel runoff (determined clinically, by computed tomography [CT] or magnetic resonance imaging [MRI] angiography), raising of the flap might impair lower leg perfusion; 3 ) in patients (especially the elderly) with arteriosclerotic vessels, anastomotic leakage might affect survival; 4) previous trauma to the lower leg might affect raising of the flap; 5) an existing lymphatic vascular condition will be exacerbated by a further flap raising intervention. Preoperative clinical examination, as well as angiography of the donor site is performed routinely in our department.

Despite its infrequent use, the subscapular system provides an excellent donor site for oromandibular reconstruction. The bone stock is sufficient for most segmental mandibular defects. The soft tissue abundance and versatility are unmatched by other composite flaps, however the soft tissue may be too bulky in obese patients and atherosclerotic vascular disease is less of an issue than in FFF [4-6]. Donor site morbidity is very low. The shoulder function following scapular tip free flap has been demonstrated to be excellent [7]. Especially the early immobilisation of elderly patients using a scapular free flap is a very important advantage over FFF.

The disadvantages of the subscapular system are the following: In the literature, pedicle length was always considered to be a disadvantage in comparison to other free flaps [8]. However, with the introduction of STFF, pedicle length of up to $17 \mathrm{~cm}$ can be achieved, yet with more limited bone stock, which makes it unsuitable for larger mandibular defects [9]. Besides pedicle length, another disadvantage of the subscapular free flaps is the length of the possible bone segment. Defects larger than $12 \mathrm{~cm}$ should be treated with FFF if possible [2]. Although the bone stock is sufficient for reconstruction of the mandible, the possibility of postoperative implant placement is questioned. Depending on placement, scapular flaps are considered as unicortical bone []․ Bone quality has also been questioned.

Therefore, the aim of this study was to evaluate the possibility of dental implant placement in patients receiving a scapular free flap for mandibular reconstruction. Furthermore, bone quality and quantity were evaluated postoperatively and one year after reconstructive surgery.

\section{MATERIAL AND METHODS}

A retrospective analysis was performed on all patients undergoing mandible reconstruction with a subscapular system free-vascularised tissue (lateral border of scapula) transfer at the University Hospital Zürich, between January 1, 2010 and January 1, 2013. The study was approved by the Institutional Ethics Committee.

Data relating to patient demographics, prior free flaps, reason for mandibular defect, flap selection, flaprelated complications, donor-related complications, radiotherapy and general medical complications were collected.

According to our Department protocol, postoperative digital volume tomography is performed immediately postoperatively to evaluate the reconstruction and available bone stock using a dental imaging system (KaVo 3DeXam DVT, KaVo Dental GmbH Biberach an der Riß, Baden-Württemberg, Germany). Imaging is repeated one year after the surgery to evaluate the possibility of dental implants. The change of height and width as well as bone density in the osseous free flap was examined on the digital imaging using integrated software of the KaVo 3DeXam. In each scapula flap, we used 12 reproducible measure points for bone height and width. Since osseous free flap is different in every patient, standardised measure points are not available. 
We used points in the areas of planned dental implants plus two additional measure points in between. We considered dental implants as feasible if the bone stock was 4 x $10 \mathrm{~mm}$ in dimension.

Bone density in cortical and cancellous bone was measured using the Hounsfield units (HU). Bone density was measured at the same points as those used for the measurement of height and width. One measurement was calculated including the cortical bone, the next measurement excluded the cortical bone, and so on.

\section{Statistical analysis}

Descriptive analysis using IBM SPSS software was conducted. Parametric data were expressed as mean and standard deviation (Mean [SD]). Changes of cancellous and cortical bone density, measured in $\mathrm{HU}$, and dimensions, measured in millimetres, were analysed using IBM SPSS Statistics 22. Comparisons of bone dimensions and density were performed using a Student's t-test. Statistical significance level was defined at $\mathrm{P}<0.05$.

\section{RESULTS}

A total of 10 patients were included in this study (Table 1). Six patients were male. Mean age was 68 years (range 54 - 77 years). Reconstruction of the mandible was necessary because of squamous cell carcinoma in 5 patients, chronic osteomyelitis in 2 patients, and osteoradionecrosis in 3 patients. In 6 patients, the reconstruction with scapular flap was the second or third free flap in the same area.

Seven patients received radiotherapy of the oromandibular region before reconstruction with the scapular free flap. Scapular free flap was elevated from the lateral border of the scapula; the bone flap was combined with a parascapular flap in 8 patients, a muscular latissimus dorsi flap in 3 patients, and a musculocutaneous flap of the latissimus dorsi in 4 patients. The bone was fixed to a reconstruction plate with a thickness of 2 or $2.5 \mathrm{~mm}$ depending on the clinical stability required. Flap survival was achieved in all patients.

Table 1. Demographic and flap details of patients treated with a scapular free flap for mandibular reconstruction

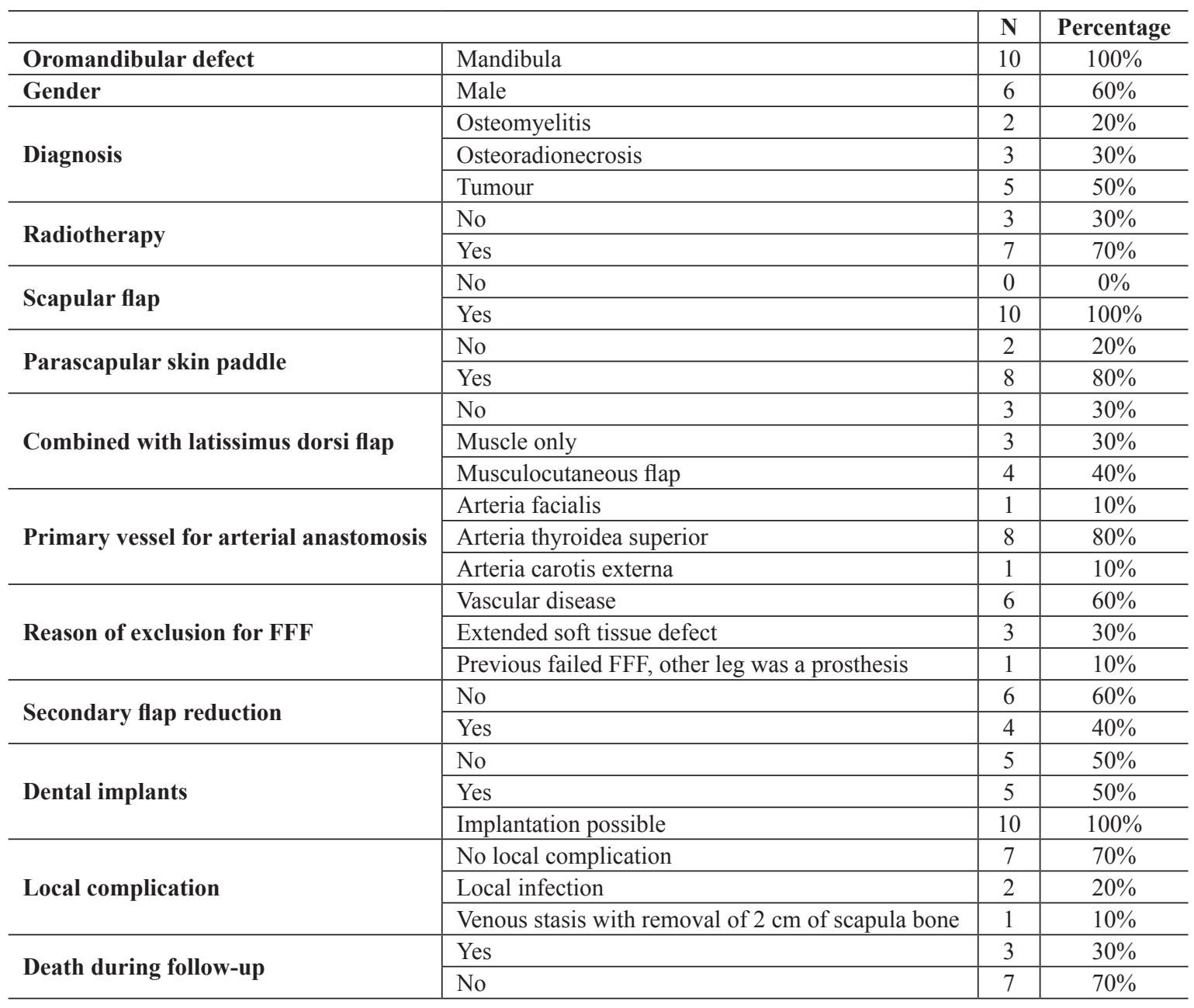

$\mathrm{N}=$ number of patients; $\mathrm{FFF}=$ fibular free flaps. 
No patient needed removal of the flap or a second flap. In one patient with venous congestion and dehiscence of the mucosa and local inflammation, $2 \mathrm{~cm}$ of the scapula bone needed to be removed due to necrosis two weeks after the operation. In another two patients, debridement was performed because of mucosal dehiscence in previously radiated fields.

Most often, vascular anastomosis was performed using the superior thyroid artery. In one patient, we used an end-to-side anastomosis to the external carotid artery; in another patient, we used the facial artery for anastomosis. In $40 \%$ of the patients, soft tissue reduction one year after insertion of the flap was necessary.

Closure of the tracheostomy wound was conducted within a mean of 17 days, discharge of the hospital in mean after 23 days, showing that all patients could be decanulated after their extensive resections within reasonable time even though this subgroup of patients could be regarded as complicated due to previous surgeries and radiotherapy (Table 2).
Loss of bone height and width was significant $(\mathrm{P}<0.001)$ within one year of examination (Figure 1A, 1B). Bone height decreased at a faster rate than bone width (Table 3). Bone morphology changed likewise. There was a statistically significant increase in bone density measured for both cortical $(\mathrm{P}<$ $0.001)$ and cancellous $(\mathrm{P}=0.004)$ bone (Table 4). In all patients, bone stock was sufficient for oral rehabilitation with oral implants. Range of bone height and width was adequate for implant placement in all patients. With the gain of bone density, bone stock was suitable for integration of implants. Only six patients received dental implants. Two patients died during follow-up, but dental implants were planned and possible in all of the patients.

Table 2. Duration of tracheostomy and hospitalisation in days

\begin{tabular}{l|c|c|c|c|c}
\hline & $\mathbf{N}$ & Minimum & Maximum & Mean & SD \\
\hline Tracheostomy & 10 & 0 & 37 & 17.8 & 12.4 \\
\hline Hospitalisation & 10 & 13 & 41 & 23.5 & 11.4 \\
\hline
\end{tabular}

$\mathrm{SD}=$ standard deviation; $\mathrm{N}=$ number of patients.

Table 3. Bone dimensions range of all patients demonstrating the possibility of dental implant placement

\begin{tabular}{|c|c|c|c|c|}
\hline \multirow{3}{*}{ Gender } & \multirow{3}{*}{$\begin{array}{l}\text { Patient } \\
\text { number }\end{array}$} & Bone height & Bone width & \multirow{3}{*}{$\begin{array}{c}\text { Dental implants } \\
\text { possible? }\end{array}$} \\
\hline & & 1 year postsurgery & 1 year postsurgery & \\
\hline & & \multicolumn{2}{|c|}{ Minimum/maximum (mm) } & \\
\hline \multirow{6}{*}{ Male } & $\mathrm{I}$ & $17 / 34$ & $10.8 / 12.8$ & Patient declined \\
\hline & II & $14.8 / 18.8$ & $10.8 / 12.4$ & 5 implants \\
\hline & III & $10 / 20.9$ & $6.4 / 10$ & 6 implants \\
\hline & IV & $15.2 / 21.3$ & $8 / 9.2$ & 6 implants \\
\hline & $\mathrm{V}$ & $11.6 / 19.2$ & $8 / 12.8$ & Patient expired \\
\hline & VI & $12.4 / 14.5$ & $8.8 / 11.2$ & 6 implants \\
\hline \multirow{4}{*}{ Female } & $\mathrm{I}$ & $16 / 16.4$ & $4.4 / 7.2$ & Patient expired \\
\hline & II & $17.2 / 21.8$ & $7.2 / 9.2$ & 6 implants \\
\hline & III & $8 / 12.7$ & $6 / 10.4$ & Patient declined \\
\hline & IV & $11.2 / 16.4$ & $7.2 / 9.2$ & 6 implants \\
\hline
\end{tabular}

Table 4. Bone density change over time, measured in Hounsfield units

\begin{tabular}{|c|c|c|c|c|c|}
\hline \multirow{3}{*}{ Gender } & \multirow{3}{*}{$\begin{array}{l}\text { Patient } \\
\text { number }\end{array}$} & \multicolumn{2}{|c|}{ Cancellous Bone } & \multicolumn{2}{|c|}{ Cortical Bone } \\
\hline & & Postsurgery & 1 year postsurgery & Postsurgery & 1 year postsurgery \\
\hline & & \multicolumn{2}{|c|}{ Mean (SD) } & \multicolumn{2}{|c|}{ Mean (SD) } \\
\hline \multirow{6}{*}{ Male } & $\mathrm{I}$ & $288(156.3)$ & $515(318.7)$ & $454.3(182.4)$ & $695.3(235.4)$ \\
\hline & II & $161.5(62.7)$ & $166.4(70.8)$ & $376.1(123.9)$ & $314.2(35.54)$ \\
\hline & III & $90(38.3)$ & $153.2(60.4)$ & $271.7(66.4)$ & $248.5(23.4)$ \\
\hline & IV & $175.2(76.8)$ & $391.2(99.7)$ & $230.5(104.4)$ & $527.5(106.4)$ \\
\hline & $\mathrm{V}$ & $161.7(72.2)$ & $186.8(85.3)$ & $338.8(85.2)$ & $395(45.9)$ \\
\hline & VI & $209.7(65.8)$ & $287.7(101)$ & $361.6(69.1)$ & $454.7(82)$ \\
\hline \multirow{4}{*}{ Female } & $\mathrm{I}$ & $203(20.1)$ & $292(41.8)$ & $578.7(23.8)$ & $747.7(21.2)$ \\
\hline & II & $175.7(86.7)$ & $436.3(95.5)$ & $443.4(211.4)$ & $715.7(182.7)$ \\
\hline & III & $268.2(102.4)$ & $288.1(41.4)$ & $676(210.3)$ & $803.1(109.1)$ \\
\hline & IV & $421.5(88.2)$ & $405.3(69.1)$ & $541.8(81.4)$ & $519.9(85.7)$ \\
\hline \multicolumn{2}{|c|}{ P-value ${ }^{a}$} & \multicolumn{2}{|c|}{$\mathrm{P}=0.004$} & \multicolumn{2}{|c|}{$\mathrm{P}<0.001$} \\
\hline
\end{tabular}

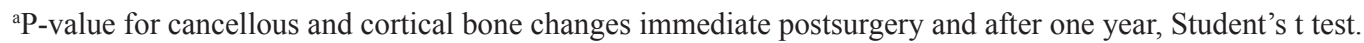
$\mathrm{P}<0.05$ was considered statistically significant.

$\mathrm{SD}=$ standard deviation 


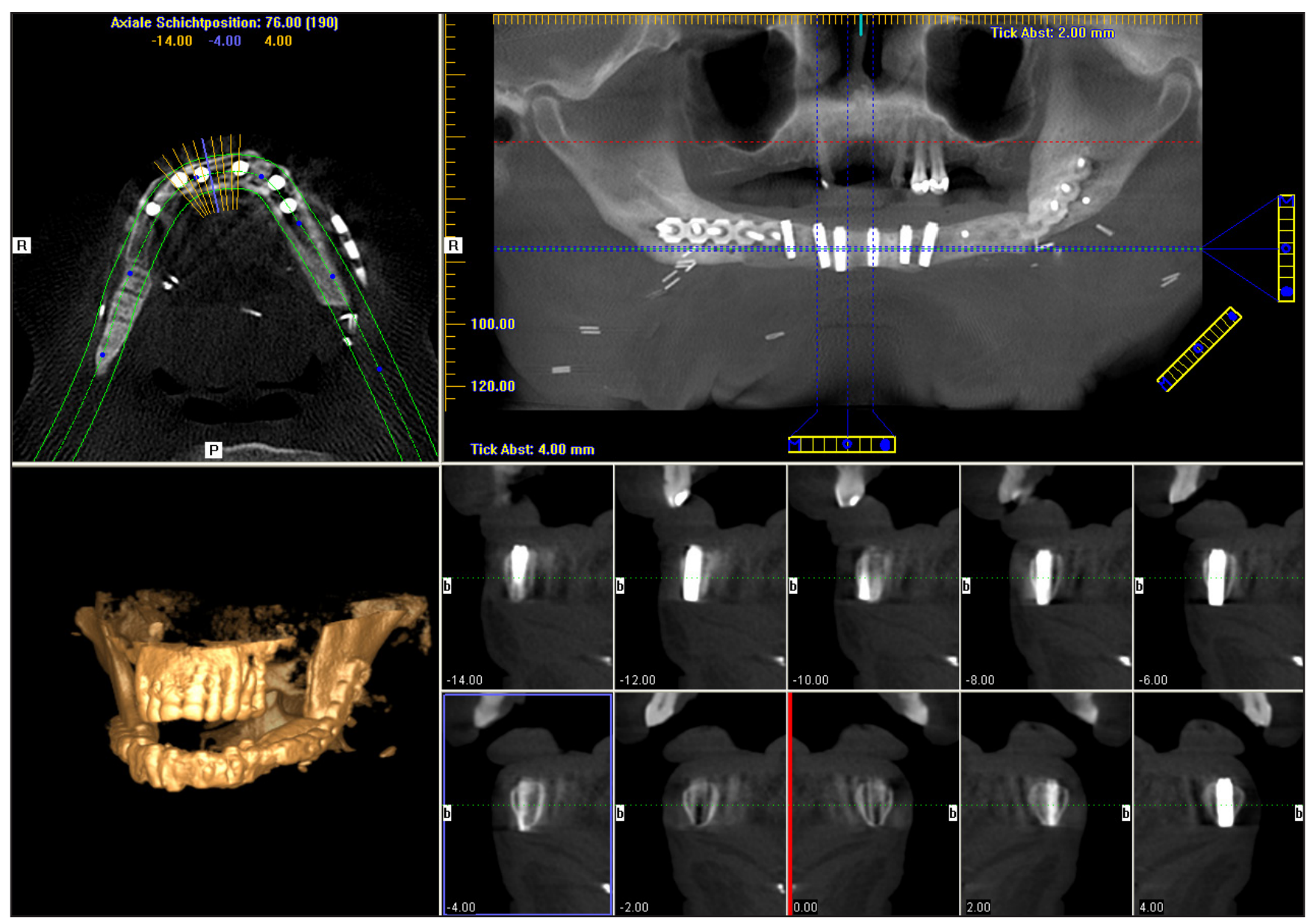

Figure 1A. Cone beam radiograph with three-dimensional reconstruction of male patient number III: one year after mandibular reconstruction with a scapula-free flap.

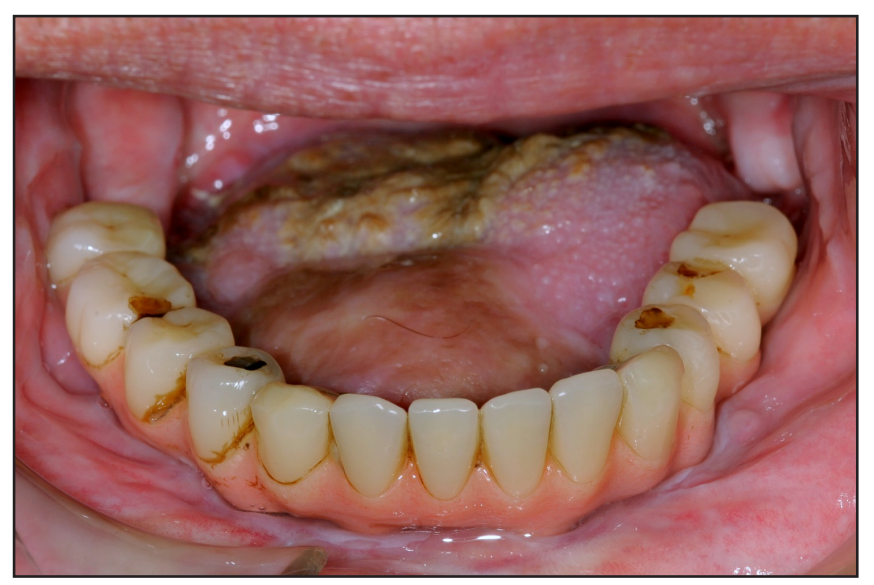

Figure 1B. Photograph of patient number III after dental rehabilitation was fulfilled.

Two patients denied any further treatment or surgery. If dental implants were planned and performed, soft tissue reduction was needed in 5 of the 6 patients.

\section{DISCUSSION}

The scapular free flap is the most versatile composite flap used for oromandibular reconstruction. It allows for replacement of bone and for restoration of large soft tissue defects [10]. Its versatility is best demonstrated by its use in combination with either horizontally oriented scapular, or vertically oriented parascapular fasciocutaneous flap. If further soft tissue is needed, the latissimus dorsi muscle with or without a skin island, or the serratus muscle with or without a segment of rib, can be harvested with the thoracodorsal artery for perfusion. Depending on the length of the bony defect, either the lateral border of the scapula or the tip of the scapula can be used. Since both bone-parts mostly rely on separate vascular systems, osteotomies are easily performed between the two, yet applied independently. Still, harvesting of the lateral border and the tip of the scapula is possible even if the amount of bone that can be harvested is limited, for example in women with lean body mass [11]. Regarding dental implants, Moscoso [12] considered the possibility of their implantation in scapula free flap only suitable in men, with the additional limitation of the proximal and distal portion of the lateral border. This opinion has to be considered to be obsolete since improvement of dental implants, especially the successful use of very short $(6 \mathrm{~mm})$ 
or narrow $(3 \mathrm{~mm})$ implants, enable implant placement in smaller bone volumes. Additionally, chewing force is considered to be significantly reduced in patients after oromandibular reconstruction, exposing dental implants to less stress than in the normal population. As described, in our patients, we considered $4 \times 10$ $\mathrm{mm}$ to be an acceptable amount of bone for dental implants. Dental implantation would have been possible in all our patients considering bone height and width (Table 3). Two female patients received dental implants (6 implants each, $3.5 \times 10 \mathrm{~mm}$; AdAstra Technologies). In the other two female patients, implant placement was refused by one patient and the other female patient died because of neoplastic disease before implant placement could be performed. Our study confirms that dental implants can be placed into the bones of scapular reconstructions in both male and female patients.

Change of bone density and bone quality for dental implants in scapular free vascularised flaps has not been evaluated in the literature so far. Radiographic follow-up of the free fibula flap after extremity reconstruction has demonstrated hypertrophy of the bone in the majority of cases [13]. Clinical and experimental data regarding the long-term changes in the fibula after mandible reconstruction have been reported [14]. Complete functional oromandibular reconstruction with dental implants after resection can be considered as the current standard of care [15]. Disa et al. [16] suggested the preservation of fibula height over time to be an indicator of the preservation of fibula bone mass, and concluded that the fibula is preserved over time. The greatest amount of bone resorption was observed in the reconstructed mandibular ramus after postoperative radiation therapy [16]. In the same study, impact of load-bearing status of the mandible did not seem to affect fibula height. Since the fibula is a long bone, formed by endochondral bone deposition, it may not be possible to extrapolate those results to intramembranous-developed scapula bone. In fact, we have observed a considerable amount of bone resorption (especially in height) in our patient. Although the individual role of stress shielding due to the positioning plate thickness as well as the level of function of the patients is important, the use of scapular free bone flaps needs further investigation. Nevertheless, the known concept of 'form follows function' was reflected in the shape and density changes of the scapula bone. Adaptive stress may cause it to imitate the changes seen in a long bone with time.

\section{CONCLUSIONS}

Dental implants are possible after scapula free flap reconstruction of oromandibular defects (Figure 1). Bone height and width were reduced, while bone density was increased. The gain of bone density offers a sound bone stock for dental implants in both women and men. The authors did not experience any problems with pedicle length during anastomosis.

\section{ACKNOWLEDGMENTS AND DISCLOSURE STATEMENTS}

The authors report no conflicts of interest related to this study.

\section{REFERNCES}

1. Urken ML, Buchbinder D, Costantino PD, Sinha U, Okay D, Lawson W, Biller HF. Oromandibular reconstruction using microvascular composite flaps: report of 210 cases. Arch Otolaryngol Head Neck Surg. 1998 Jan;124(1):46-55. [Medline: 9440780$]$ [doi: 10.1001/archotol.124.1.46]

2. Dowthwaite SA, Theurer J, Belzile M, Fung K, Franklin J, Nichols A, Yoo J. Comparison of fibular and scapular osseous free flaps for oromandibular reconstruction: a patient-centered approach to flap selection. JAMA Otolaryngol Head Neck Surg. 2013 Mar;139(3):285-92. [Medline: 23657276] [doi: 10.1001/jamaoto.2013.1802]

3. Shpitzer T, Neligan P, Boyd B, Gullane P, Gur E, Freeman J. Leg morbidity and function following fibular free flap harvest. Ann Plast Surg. 1997 May;38(5):460-4. [Medline: 9160127] [doi: 10.1097/00000637-199705000-00005]

4. Brown J, Bekiroglu F, Shaw R. Indications for the scapular flap in reconstructions of the head and neck. Br J Oral Maxillofac Surg. 2010 Jul;48(5):331-7. [Medline: 19913337] [doi: 10.1016/j.bjoms.2009.09.013]

5. Chepeha DB, Khariwala SS, Chanowski EJ, Zumsteg JW, Malloy KM, Moyer JS, Prince ME, Sacco AG, Lee JS. Thoracodorsal artery scapular tip autogenous transplant: vascularized bone with a long pedicle and flexible soft tissue. Arch Otolaryngol Head Neck Surg. 2010 Oct;136(10):958-64. [Medline: 20956740] [doi: 10.1001/archoto.2010.166]

6. Hwang JH, Hwang K, Bang SI, Kim DI, Han SH. Reliability of vascular territory for a circumflex scapular artery-based flap. Plast Reconstr Surg. 2009 Mar;123(3):902-9. [Medline: 19319054] [doi: 10.1097/PRS.0b013e318199f03b]

7. Clark JR, Vesely M, Gilbert R. Scapular angle osteomyogenous flap in postmaxillectomy reconstruction: defect, reconstruction, shoulder function, and harvest technique. Head Neck. 2008 Jan;30(1):10-20. [Medline: 17636540] [doi: 10.1002/hed.20649] 
8. Lin CT, Leung JK, Chen JS, Yang KC. Combined free fibularb osteocutaneous-lateral calcaneal fasciocutaneous flap for reconstruction of composite oromandibular defects. Ann Plast Surg. 2004 Nov;53(5):442-8. [Medline: 15502459] [doi: $10.1097 / 01 . s a p .0000130710 .64793 .0 \mathrm{~b}$ ]

9. Seitz A, Papp S, Papp C, Maurer H. The anatomy of the angular branch of the thoracodorsal artery. Cells Tissues Organs. 1999;164(4):227-36. [Medline: 10436331] [doi: 10.1159/000016663]

10. Bak M, Jacobson AS, Buchbinder D, Urken ML. Contemporary reconstruction of the mandible. Oral Oncol. 2010 Feb;46(2):71-6. [Medline: 20036611] [doi: 10.1016/j.oraloncology.2009.11.006]

11. Urken ML, Bridger AG, Zur KB, Genden EM. The scapular osteofasciocutaneous flap: a 12-year experience. Arch Otolaryngol Head Neck Surg. 2001 Jul;127(7):862-9. [Medline: 11448364]

12. Moscoso JF, Keller J, Genden E, Weinberg H, Biller HF, Buchbinder D, Urken ML. Vascularized bone flaps in oromandibular reconstruction. A comparative anatomic study of bone stock from various donor sites to assess suitability for enosseous dental implants. Arch Otolaryngol Head Neck Surg. 1994 Jan;120(1):36-43. [Medline: 8274254] [doi: 10.1001/archotol.1994.01880250032004]

13. Doi K, Kawakami F, Hiura Y, Oda T, Sakai K, Kawai S. One-stage treatment of infected bone defects of the tibia with skin loss by free vascularized osteocutaneous grafts. Microsurgery. 1995;16(10):704-12. [Medline: $\underline{8676735]}$ [doi: 10.1002/micr.1920161009]

14. Jacobsen C, Lübbers HT, Obwegeser J, Soltermann A, Grätz KW. Histological evaluation of microsurgical revascularized bone in the intraoral cavity: does it remain alive? Microsurgery. 2011 Feb;31(2):98-103. [Medline: 21280106] [doi: $10.1002 / \mathrm{micr} .20858$ ]

15. Jacobsen C, Kruse A, Lübbers HT, Zwahlen R, Studer S, Zemann W, Seifert B, Grätz KW. Is mandibular reconstruction using vascularized fibula flaps and dental implants a reasonable treatment? Clin Implant Dent Relat Res. 2014 Jun;16(3):419-28. [Medline: 22998581] [doi: 10.1111/cid.12004]

16. Disa JJ, Winters RM, Hidalgo DA. Long-term evaluation of bone mass in free fibula flap mandible reconstruction. Am J Surg. 1997 Nov;174(5):503-6. [Medline: 9374225] [doi: 10.1016/S0002-9610(97)00152-9]

\section{To cite this article:}

Lanzer M, Gander T, Grätz K, Rostetter C, Zweifel D, Bredell M.

Scapular Free Vascularised Bone Flaps for Mandibular Reconstruction: Are Dental Implants Possible?

J Oral Maxillofac Res 2015;6(3):e4.

URL: http://www.ejomr.org/JOMR/archives/2015/3/e4/v6n3e4.pdf

doi: $10.5037 /$ jomr.2015.6304

Copyright (c) Lanzer M, Gander T, Grätz K, Rostetter C, Zweifel D, Bredell M. Published in the JOURNAL OF ORAL \& MAXILLOFACIAL RESEARCH (http://www.ejomr.org), 30 September 2015.

This is an open-access article, first published in the JOURNAL OF ORAL \& MAXILLOFACIAL RESEARCH, distributed under the terms of the Creative Commons Attribution-Noncommercial-No Derivative Works 3.0 Unported License, which permits unrestricted non-commercial use, distribution, and reproduction in any medium, provided the original work and is properly cited. The copyright, license information and link to the original publication on (http://www.ejomr.org) must be included. 